\title{
Guidelines to the Management of Firefly Watching Tour in Thailand
}

\author{
Panan Nurancha ${ }^{1}$, Wasin Inkapatanakul ${ }^{1} \&$ Kasem Chunkao $^{1}$ \\ ${ }^{1}$ Faculty of Environment, Kasetsart University, Bangkok, Thailand \\ Correspondence: Panan Nurancha, Faculty of Environment, Kasetsart University, Bangkok 10900, Thailand. \\ E-mail: pnurancha@yahoo.com
}

Received: January 16, 2013

Accepted: February 1, $2013 \quad$ Online Published: February 7, 2013

doi:10.5539/mas.v7n3p8

URL: http://dx.doi.org/10.5539/mas.v7n3p8

\begin{abstract}
This article presents findings from the study on "Guidelines to the Management of Firefly Watching Tour in Thailand". The study utilized the Delphi technique and 18 experts in 6 fields, namely entomology, mangrove forest, tourism, environment, economy and social science. It reveals the first three priorities for management that include: 1) Campaigning and working on public relations for the conceptual change from the mainstream tour to 'eco-friendly tour' through conservation or restoration-related activities and participation from tourists; 2) Managing the tourism based on understanding in nature and; 3) Monitoring environmental changes, both physically and biologically, on a constant basis with collaboration from concerned parties such as Sub-district Administration Organization (SAO), local tour companies and community leaders to create the direction and appropriate patterns of firefly watching tour. Among findings is the management that highly requires collaboration from local people and participation from concerned parties including tour companies, local agencies such as Sub-district Administration Organization (SAO) and municipalities, state agencies and tourists. Furthermore, the finding highlights the use of youth power in order to strengthen the awareness in environment and nature preservation in local communities. By using this, youth will be instilled with knowledge through curriculum at kindergarten, elementary and secondary level. At the end, the nature preservation will exist in them since young ages, along with the sustainability of preservation in their communities.
\end{abstract}

Keywords: management, tourism, firefly, Delphi technique

\section{Introduction}

In the present, many developing countries use tourism as a key strategy to country development. Their government put efforts to develop and promote tourism industry to stimulate the economic growth. Thus, at the same time, unplanned and uncontrolled tourism can damage the country's natural resources and environment (Creaco \& Querini, 2003). Giving Thailand as an example, the growth of tourism industry has produced impacts on the firefly watching tour, which later results in the loss of habitat for fireflies.

Among living creatures, the firefly is commonly an insect that symbolizes the fertility and balance of nature (Botanical Garden Organization, 2003) because the life cycle of firefly is closely tied with the environment and nature's fertility. However, studies about the firefly are very rare in Thailand. This study, therefore, had put an attempt and finally could categorize species of some families, namely Luciola circumdata, L. ovalis, $L$. substriata, and L. aquatilis (Thancharoen et al., 2007) Pteroptyx mallaccae, Pyrocoelia analis, P. praetexta, P. tonkinensis, $P$. grata, Pyrophanes indica. The fireflies produce and synchronize blinking lights at night that signal to attract mates. Each species synchronize the light differently (Botanical Garden Organization, 2003). Blinking lights create beautiful nights, like Christmas trees, that invite tourists to visit.

Due to population increase which is followed by an extension of cities, people heavily use pesticides that pollute water sources, the air and soil as well as cause a salt balance change in rivers. These mentioned leads to a significant decrease in firefly population (Lloyd et al., 1994; Nada \& Kirton, 2004; Nada et al., 2009). In Thailand, the growth of tourism industry is a key factor to a constant decrease of firefly population as obviously seen in Amphawa, Samut Songkhram. A huge income from tourism comes with a continuous increase of tourist number that further results in higher population density as well (Chiravet, 2005). Changes take place and so do negative impacts on the communities, for example sales of land and farms along the river and canals to serve as accommodations for increasing tourists. The increasing number of boat also brings in social and environmental impacts on the community. Such impacts include noise pollution that disturbs people living along the water and 
shrimp farmers and water pollution from motor oil that spills down into the river (Tironparin, 2005). Both direct and indirect impacts happen to the life of fireflies and cause a constant reduction in number.

It is, therefore, crucial for Thailand to seek tourism management with least impacts on firefly population and community. In this study, the management is focused on the conservation and expected to yield benefits to stakeholders for policy making for the sustainability of cohabitation among communities, environment and tourism.

\section{Literature Review}

\subsection{Firefly}

The firefly is a beetle in the Family Lampyridae, Order Coleoptera. There are around 2,000 species in the world (McDermott, 1966). In Thailand, more than 100 species in 9 families are found (Sommai \& A-ngoon, 1998) and people name the firefly differently, but most call it "Hing-hoi".

A firefly has 4 stages in its life cycle, beginning with an egg, then a larva, pupa and adult (See Figure 1). Generally, fireflies gather around on trees and synchronize blinking lights after sunset (Lloyd, 1971; Suzuki et al., 1996; Copeland \& Moiseff, 1997). Both male and females blink their lights symbolizing sexual communication. Larvae eat small animals while adults can live no longer than 2 weeks, with little eating or not eating at all. Water and flower syrup are food for adult fireflies. In general, fireflies find food and mate to lay eggs when the sky gets dark and before the dawn breaks. After laying eggs, females will not live long. For fireflies, it takes 3 months to one year for a complete life cycle and this depends on the species and environment (Krit, 1998; Burger, 1994).

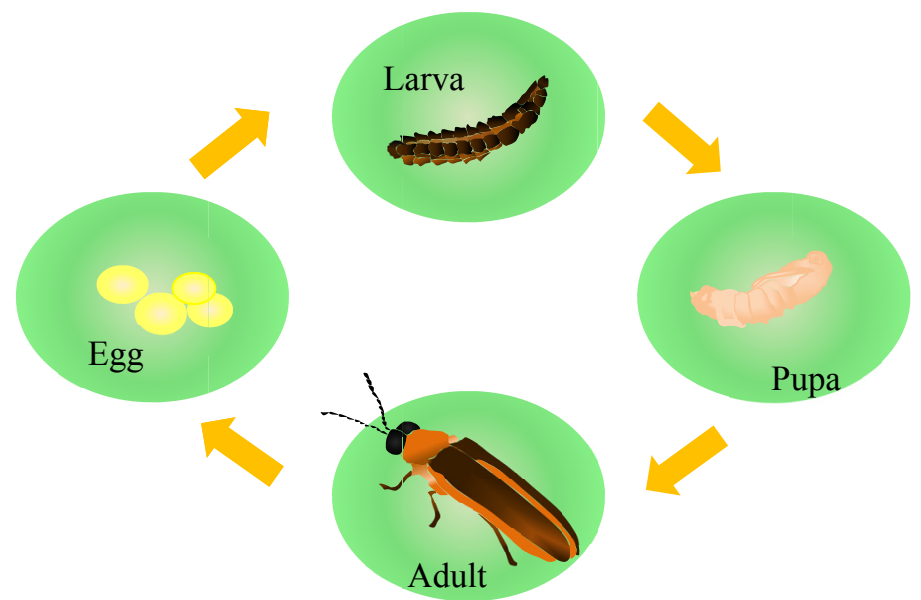

Figure 1. Firefly life cycle

Many spots for firefly watching tours exist in Thailand, particularly in mangrove forest areas such as the mouth of Mae Klong River in Samut Songkhram, Bang Pa Kong River in Chacheungsao and Prasae River in Rayong. The most popular sites are located in Samut Songkhram where Pteroptyx species, Pteroptyx Malaccae Gorham and Pteroptyx valida, are found at the river mouth having brackish water and in mangrove forests. These lighting bugs gather on some trees, namely Sonneratia ceaeolaris Engler, Avicennia spp. and Nypa frutican Wurmb (Buck, 1988).

Sunisa Loombutr conducted a laboratory study in 2008 on the biology and ecology of Pteroptyx malaccae Gorham and found that the life cycle of this species averaged 122.90 days to fully grow. In the cycle, eggs lasted in 12.15 days, the larval stage ended in around 97.83 days, fireflies remained in their pupas for 9.83 days and adult fireflies lived for 12.33 days after emerging from pupa cases. This species eat gastropods, specially red berry snails or Assiminea sp. (Loombutr, 2008). Fireflies can be found all year round, but the number depends on the season. So September and October or end of rainy season is the period for a large number of fireflies. In Thailand, river mouth areas attract many fireflies and so night tours by boat is the pattern to see them.

\subsection{Impacts from Firefly Watching Tour}

Previous studies indicated that firefly watching tours produced impacts on firefly population and people in the tour area. As reported by Buck $(1966,1968) 40$ years ago, Thailand had a high firefly density. However, firefly habitats were destroyed and constantly decreased due to geographical changes (Thancharoen, 2007). This 
resulted in a continuous decrease of firefly number. In fact, mangrove forest encroachment was also a major reason to the decrease of fireflies in brackish water sources as an example in Malaysia where the cut down of Sonneratia ceaeolaris Engler in the Selangor River area caused a reduction in number of Pteroptyx tener fireflies (Nallakumar, 2003). Additionally, firefly watching tours by boat in rivers or mangrove forest areas contributed a reduction in firefly population because the tour disturbed the habitat area. According to Suchada et al. (2007), firefly watching tours in Amphawa, Samut Songkhram caused a huge reduction in number and distribution of Pteroptyx malaccae Gorham which contrasted with an increasing popularity of the tour.

\subsection{Delphi Technique}

The Delphi technique was developed by Olaf Helmer and Norman Dalkey from the Rand Corporation in early 1950 aimed at questioning and collecting opinions of experts on the prediction in science and technology. The Delphi technique systematically facilitates the analysis or decision making of experts without any confrontation between them. This way, each expert can freely express their opinions, without worry about others', and has chances to carefully review these opinions, making them reliable for decision making (Czinkota \& Ronkainen, 1997; McGill, 1988; Robbins, 1996; Stewart et al., 1999).

Delphi starts with the selection of experts to answer the questionnaire of which questions are repeated in many rounds for more and more reliable opinions. Open-ended questionnaire composed of general questions are used in the first round to gather opinions from each expert. All first round opinions are analyzed and similar or overlapping opinions are cut off. Then, the researcher develops the second round questionnaire and sends it to the same experts to verify their answers. However, the second round and next rounds apply the close-ended questionnaire. The rating scale for each round varies and the questionnaire will be stopped when the conformity of answers or opinions is met (Delbecq et al., 1975; Lang, 1998; Ludwig, 1997).

Considering the expert number, Delbecq et al. (1975) recommended 15-20 experts, rather than having 3-4 experts which were considered too few. However, Linstone and Turoff (1975) suggested 5-10 persons while Thomas Macmillan proposed 17 experts and over to lessen errors.

\section{Research Methodology}

\subsection{Population}

This study involved in 18 experts, from the field of entomology, mangrove forest, tourism, environment, economy and social science, which were selected according to criteria set by the researcher.

\subsection{Step}

Firstly, the researcher did literature review through books and research documents about the firefly and impacts from tourism on firefly population. The review helped develop the open-ended questionnaire and, then, 18 experts from 6 fields were selected. The researcher made appointments to meet, inform them research objectives and invite them as experts for this research. After this, they were asked to answer open-ended questions in the first round. After collecting all answers from 18 experts, the researcher analyzed and cut out overlapping answers in order to construct the close-ended questionnaire with rating scales. This questionnaire was sent out again to them to rank order of scales and certify their answers.

\subsection{Statistics for Analysis}

This study utilized mean, standard deviation (S.D.), median and Interquartile Range (IR) with statistical interpretation as follows:

1) Mean value should get higher than 3.41

2) Standard deviation was set under 1.20 which implied less score distribution or harmonized opinions

3) Median was set higher than 3.41

4) Interquartile range should not get higher than 1.50

\section{Findings}

Most experts, 93.33 percent, viewed that the sustainable success of firefly watching tour management needed the participation of community people to take role in tourism management (Figure 2). 66.67 percent recommended the involvement of state sector in the management while 33.33 percent agreed with the state provision of supports, such as knowledge and budget, to the community when requested only (Figure 3). 


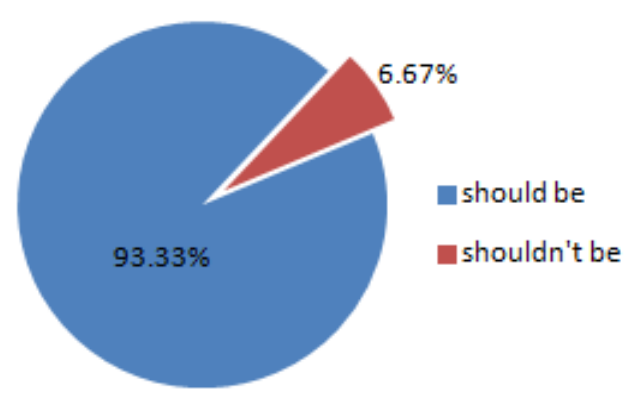

Figure 2. Percentage of opinions from experts on the role of community people and participation in firefly watching tour management

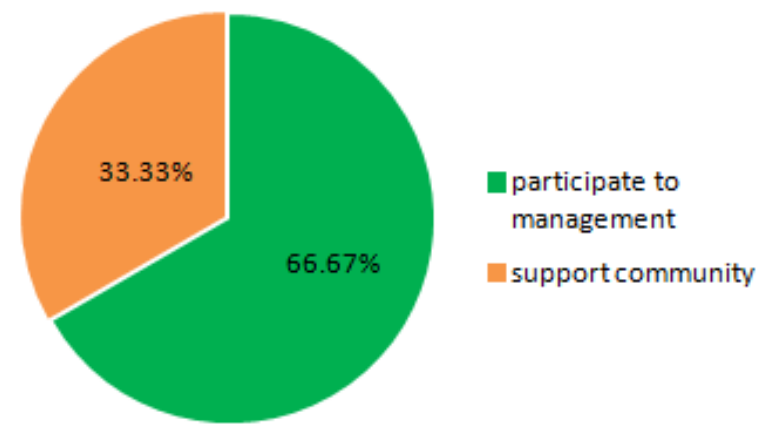

Figure 3. Percentage of opinions from experts on the role of state and participation in firefly watching tour management

Table 1 presents how to successfully and sustainably manage the firefly watching tour and Table 2 presents the state participation for success and sustainable management of the firefly watching tour.

Table 1. Guidelines to successful and sustainable management of firefly watching tour

\begin{tabular}{|c|c|c|c|c|}
\hline Guidelines to firefly watching tour management & Mean & S.D. & Median & IR \\
\hline $\begin{array}{l}\text { 1. There need to be realization in nature system before bringing firefly } \\
\text { watching tours and tourists into communities. }\end{array}$ & 4.890 & 0.323 & 5.00 & 0 \\
\hline $\begin{array}{l}\text { 2. SAO and Tourism Authority of Thailand are required to have } \\
\text { proactive plans to provide tourists knowledge about firefly life cycle } \\
\text { and appropriate tour patterns. }\end{array}$ & 4.610 & 0.698 & 5.00 & 1.00 \\
\hline $\begin{array}{l}\text { 3. SAO should take action to build awareness in natural resource and } \\
\text { environment conservation in community people. }\end{array}$ & 4.830 & 0.383 & 5.00 & 0 \\
\hline $\begin{array}{l}\text { 4. Youth power should be promoted to strengthen awareness in } \\
\text { conservation of local nature and resources. }\end{array}$ & 4.780 & 0.428 & 5.00 & $\begin{array}{c}0.25 \\
0\end{array}$ \\
\hline $\begin{array}{l}\text { 5. Local firefly clubs/groups should be established for regulating the } \\
\text { firefly watching tour along with rules and regulations acceptable to all. }\end{array}$ & 4.560 & 0.511 & 5.00 & 1.00 \\
\hline $\begin{array}{l}\text { 6. Funds should be established for conservation and restoration of } \\
\text { firefly colonies. The fund should have activities such as providing } \\
\text { information boards for tourists and locating buoys to prevent boats } \\
\text { from getting close to fireflies. }\end{array}$ & 4.330 & 0.686 & 4.00 & 1.00 \\
\hline $\begin{array}{l}\text { 7. There should be forums on firefly watching tour to share knowledge } \\
\text { among academics, interested public and concerned people in } \\
\text { communities and to lay down work plans and activities. }\end{array}$ & 4.500 & 0.618 & 5.00 & 1.00 \\
\hline
\end{tabular}


8. Campaigns and public relations works should be highlighted for conceptual changes in tourists, from popular tour to eco-friendly one that involves them in conservation and restoration activities.

9. Local communities should be participated in the management rather than giving the same to some groups of people.

10. There should be a website for networking and sharing information about sustainable firefly watching tour.

11. Measures and regulations on land sales, investment and tourist number should be set according to the capacity of areas for tourism.

12. SAO/local leaders/local tour companies should monitor changes, physically and biologically, on a constant basis for appropriate direction and patterns of firefly watching tour. $\begin{array}{llll}4.890 & 0.323 & 5.00 \quad 0\end{array}$

$\begin{array}{llll}4.830 & 0.383 & 5.00 & 0\end{array}$

$\begin{array}{llll}4.440 & 0.705 & 5.00 & 1.00\end{array}$

$\begin{array}{llll}4.280 & 0.752 \quad 4.00 \quad 1.00\end{array}$

$\begin{array}{llll}4.890 & 0.323 \quad 5.00 & 0\end{array}$

Table 2. Guidelines to state participation to successful and sustainable management of firefly watching tour

Guidelines to state participation in firefly watching tour Mean S.D. Median IR management

1. The state sector should conduct a study on geography and preparation of the community to assess the possibility and worthiness as tourist attraction.

2. The state should provide supports to communities.

$\begin{array}{llll}4.560 & 0.984 & 5.00 \quad 0.25\end{array}$

3. The state should set up learning centers for firefly conservation in communities and organize training to staff on biology and ecology of firefly.

$\begin{array}{llll}4.500 & 0.786 & 5.00 & 1.00\end{array}$

4. The state should build up awareness and promote people's participation to better understand about benefits of conservation to the living, economy and society

5. Campaign on conservation of firefly breeding area should be raised.
$\begin{aligned} & \text { 6. Local wisdoms such as cultures, traditions and history should be } \\ & \text { promoted in tourists. }\end{aligned}$
$\begin{aligned} & \text { 7. Both state sector and community should find measures to control boat } \\ & \text { tours and tour period (in-season and off-season) for self-restoration of } \\ & \text { nature. }\end{aligned}$
$\begin{aligned} & \text { 8. The state sector should support research on community tourism } \\ & \text { management plan, strengthen skills and knowledge in tourism } \\ & \text { management for community and do networking among concerned } \\ & \text { communities. }\end{aligned}$

\section{Conclusion}

For success and sustainability, community people should participate in the firefly watching tour management as they are stakeholders and understand well their local nature. The community-based participation is recommended, along with a clear structure of management suitable for each community as well as a monitoring and evaluation system at community level. Other people in the communities should get involved for better collaboration. That is to say, all people should help with thinking, acting and evaluating. Importantly, there should be forums organized for experience sharing with academics and public. Besides knowledge exchanges, these forums empower the community and inputs from forums will facilitate work plans and appropriate activities. Most importantly, knowledge transfer to the next generation is the major factor to achieve the sustainable management. For children, they need socialization and internationalization, and learning in culture and proper social value. All could be done through activities and curriculum for kindergarten, elementary and secondary education. By having these, young generation will be the key to sustainable management in the future. 
Furthermore, this way is same the way to management firefly watching in Malaysia. That information such as firefly's life cycle and habitat must has been imparted to the community through several firefly awareness programs organized for local villagers, tour guides, boat operators and school children (Nada et al., 2009).

About the state sector, they should focus on public relations targeted at community people for a recognition of and understanding in natural occurring resources. These natures are significant to the community's economy and life in the long term, particularly the income generated by true natural legacy, not man-made ones. The state should provide communities supports that should also come with the community's preparation. Therefore, it is neither instruction nor determination from any government bodies, but networks of collaboration established by communities. Their own initiative will survive with minor supports from state agencies that include provision of knowledge, campaign for sustainable management and other public relations. Moral supports from the state, such as award provision, are also considered as a value added to the community. This creates a notion among people that it is not just money, but benefits to the whole society.

\section{Recommendation}

This study recommends constant awareness raising, based on biology, ecology and ethnology of the firefly, in nature conservation among people. This basis should also be part of public relations. Internal schools should be set as a center for community learning as well as for visitors. Networks of community people, visitors, entrepreneurs, government bodies and general public are also recommended for information sharing. Furthermore, the network is expectedly for the realization of fireflies as a crucial element to ecology, ecological cohabitation and social relationship. Information through networks and website will result in positive perception towards the firefly watching tour that can be adapted to other ecological initiatives.

\section{Acknowledgment}

This research received financial supports from the National Research Council of Thailand (NRTC).

\section{References}

Botanical Garden Organization. (2003). Hing-hoi in Thailand (in Thai). Ministry of Natural Resources and Environment.

Buck, J., \& Buck, E. (1966). Biology of synchronous flashing of fireflies. Nature, 3, 562-564. http://dx.doi.org/10.1038/211562a0

Buck, J., \& Buck, E. (1968). Mechanism of rhythmic synchronous flashing of fireflies. Science, 159, 1319-1327. http://dx.doi.org/10.1126/science.159.3821.1319

Buck, J. (1988). Synchronous flashing of fireflies II. Q. Rev. Biol., 63, 263-281. http://dx.doi.org/10.1086/415929

Burger, D. R. (1994). Fireflies in Houston. Forest Preserve District of Cook country. lllinois.

Copeland, J., \& Moiseff, A. (1997). The effect of flash duration and flash shape on entrainment in Pteroptyx malaccae, a synchronic Southeast Asain firefly. J. Insect Physiol., 43, 965-971. http://dx.doi.org/10.1016/S0022-1910(97)00034-6

Creaco, S., \& Querini, G. (2003). The Role of Tourism in Sustainable Economic Development Development. 43rd Congress of European Regional Science Association.

Czinkota, M. R., \& Ronkainen, I. A. (1997). International business and trade in the next decade: Report from a Delphi Study. Journal of International Business Studies, 28(4), 827-844. Retrieved from http://www.jstor.org/discover/10.2307/155496?uid=3737800\&uid=2\&uid=4\&sid=21101734291847

Delbecq, A., Van de Ven, A., \& Gustafson, D. (1975). Group techniques for program planning: A guide to Nominal group and Delphi processes. Glenview, IL: Scott-Foresman.

Homdorg, K. (1998). Hing-hoi Pyrocoelia analis Fabricius (in Thai). Special Problem in entomology at bachelor degree level, Department of Entomology, Faculty of Agriculture, Chiang Mai University, Chiang Mai.

Lang, T. (1998). An overview of four future methodologies. Retrieved September 2009 from http://www.soc.hawaii.edu/future/j7/LANG.html

Linstone, H. A., \& Turoff, M. (1975). The Delphi method: Techniques and applications. Reading, Massachusetts: Addison-Wesley.

Linsenmaier, W. (1972). Insects of the Flash Communication System in Photinus Fireflies. Museum of Zoology, University of Michigan. 
Lloyd, J. E. (1971). Bioluminescent communication in insects. Annual Review of Entomology, 16, 97-122. http://dx.doi.org/10.1146/annurev.en.16.010171.000525

Lloyd, J. E., Ballatyne, L., Forrest, T., \& Wing, S. (1994). Fireflyer Companion \& Letter, 1(1), Winte 1993-1994. Retrieved from http://ufdc.ufl.edu/UF00089448/00001/1j

Loombutr, S. (2008). Technique in raising and developing natural conditions for hing-hoi Pteroptyx malaccae Gorham. PhD thesis, Kasetsart University.

Ludwig, B. (1997). Predicting the future: Have you considered using the Delphi methodology? Journal of Extension, 35(5). Retrieved November 2009 from http://www.joe.org/joe/1997october/tt2.html

McDermott, F. A. (1966). Lampyridae. In: Steel WO, editor. Coleopterorum Catalogus Supplementa, pars 9 (editio secunda): S-Gravenhage: W. Junk. pp. 1-149.

McGill, J. L. (1988). Computer competencies needed by secondary teachers to be proficient using microcomputers in teaching. Unpublished doctoral dissertation, Kansas State University.

Nada, B., \& Kirton, L. G. (2004). The secret life of fireflies. IRBM Updates, No. 3 (December 2004), pp. 2-4.

Nada, B., Kirton, L. G., Norma-Rashid, Y., \& Khoo, V. (2009). Conservation efforts for the synchronous fireflies of the Selangor River in Malaysia. Diversity and Conservation of Fireflies. Proceedings of the International Symposium on Diversity and Conservation of Fireflies, Queen Sirikit Botanic Garden, Chiang Mai, Thailand, 26-30 August 2008 (ed. by B. Napompeth), pp. 160-171. Queen Sirikit Botanic Garden, Chiang Mai, Thailand.

Nallakumar, K. (2003). The synchronously flashing aggregative fireflies of peninsular Malaysia. Biodiversity, 4, 11-16. http://dx.doi.org/10.1080/14888386.2003.9712684

Robbins, S. (1996). Organizational behavior: Concepts, applications \& controversies (6th ed.). New York: Prentice-Hall Publishing.

Sommai, C., \& A-ngoon, L. (1998). Hing-hoi (in Thai). Kasikorn Newspaper, 71(1), 33-37.

Stewart, J., O’Halloran, C., Harrigan, P., Spencer, J. A., Barton, J. R., \& Singleton, S. J. (1999). Identifying appropriate tasks for the pre-registration year: Modified Delphi Technique. British Medical Journal, 319(7204), 224-229. http://dx.doi.org/10.1136/bmj.319.7204.224

Suchada, K., Poonpong, S., Wanlada, V., Supalak, S., \& Touchtarit, T. (2007). People's participation in impact management of firefly tour: Cast study of Amphawa Canal, Samut Songkhram Province (in Thai). Faculty of Education, Burapha University.

Suzuki, H., Sato, Y., Fujiyama, S., \& Ohba, N. (1996). Biochemical systematic of Japanese Fireflies of the Subfamily Luciolinae and Their Flash Communication Systems. Biochemical Genetics, 34, 191-200. http://dx.doi.org/10.1007/BF02407019

Thancharoen, A. (2007). The Biology and Mating Behavior of an Aquatic Firefly Species, Luciola aquatilis sp. Nov. Thancharoen (Coleoptera: Lampyridae). PhD thesis, Mahidol University.

Thancharoen, A., Ballantyne, L. A., Branham, M. A., \& Jeng, M. L. (2007). Description of L. aquatilis sp. nov., a new aquatic firefly (Coleoptera: Lampyridae: Luciolinae) from Thailand. Zootaxa, 1611, 55-62. 